\title{
Dinâmica da Mediação
}

Orientador: Prof. Abimar Oliveira de Moraes

Pesquisadora: Dione Prado Lopes

Projeto de Pesquisa: Questões Atuais de Teologia Pastoral

Fonte: $\mathrm{CNPq}$

A pesquisa tinha como objetivo Identificar, a partir do pensamento de Jean-François Six, os "setores da mediação" dando especial atenção à mediação sócio-teológica. Fazendo um levantamento de um referencial teórico a fim de obter uma maior aproximação entre teoria e práxis, elemento fundamental para uma correta compreensão e aplicação da disciplina designada como Teologia Pastoral.

Foram apontados os elementos principais que o autor considera para uma mediação dita 'aberta' e de via positiva. A visão que tem do mediador, da mediação e dos mediandos.

A conclusão da pesquisa é que a mediação é feita no cotidiano das relações pessoais e sociais, tanto para casos particulares ou institucionais, quanto para sociais ou internacionais. A mediação é política no sentido de interesse de levar aos cidadãos sua formação. A mediação leva a cidadania. 